\title{
BRINCANDO, LENDO E CONTANDO HISTÓRIAS NA EDUCAÇÃO INFANTIL: UMA ABORDAGEM CRIATIVA COM O CONTO DE FADA CORDELIZADO, PINÓQUIO
}

\author{
PLAYING, READING AND TELLING STORIES IN CHILD EDUCATION: \\ A CREATIVE APPROACH TO THE CORDELIZED FAIRY TALE, PINOCKIO
}

\author{
Nadilza Maria de Farias Souza ${ }^{1}$ \\ Naelza de Araújo Wanderley ${ }^{2}$
}

Resumo: Este estudo apresenta a Literatura de Cordel como possibilidade de desenvolver a leitura literária na Educação Infantil. Os textos escolhidos para análise foram as adaptações em cordel: Pinóquio: ou o preço da mentira (2009), de Manoel Monteiro e Pinóquio (2015), de Sírlia Sousa de Lima. Desse modo, trazemos reflexões acerca de metodologias e práticas de leitura literária que possibilitam uma maior proximidade da criança com o texto literário de maneira criativa e lúdica embasando-nos nos estudos de Aguiar e Bordini, (1988) e de Girotto e Souza (2010). Acreditamos que os métodos apresentados podem contribuir para a formação de leitores.

Palavras-chave: literatura de cordel; metodologia; estratégias; educação infantil.

Abstract: This study presents Cordel Literature as a possibility to develop literary reading in early childhood education. The texts chosen for analysis were adaptations in string: Pinocchio: or the price of lies (2009), by Manoel Monteiro and Pinocchio (2015), by Sírlia Sousa de Lima. Thus, we bring reflections on methodologies and practices of literary reading that allow a closer proximity of the child with the literary text in a creative and playful way based on the studies of Aguiar and Bordini, (1988) and Girotto e Souza (2010). We believe that the methods presented can contribute to the formation of readers.

Keywords: cordel literature; methodology; strategies; child education.

\section{Introdução}

Quando falamos em ensinar literatura não pensamos imediatamente no público infantil, por achar que este não tem maturidade suficiente para entender os livros e os textos. Na verdade, trata-se de um equívoco que por muito tempo povoou a mente de professores e pesquisadores. É possível observar esse fenômeno nos primeiros textos que hoje fazem parte do repertório

\footnotetext{
${ }^{1}$ Mestranda do Programa de Pós Graduação em Linguagem e Ensino (PPGLE) da Universidade Federal de Campina Grande (UFCG). E-mail: nadilza43.net@gmail.com

${ }^{2}$ Professora do Programa de Pós Graduação em Linguagem e Ensino (PPGLE) da Universidade Federal de Campina Grande (UFCG). E-mail: naelzanobrega@ig.com.br
} 
infantil, eles não foram originalmente escritos para crianças, mas, no decorrer do tempo, foram adaptados e tornaram-se clássicos da Literatura Infantil, são os contos de fadas.

A escola é o lugar onde esse repertório se faz presente e se alarga, possibilitando novas leituras e o encontro entre as crianças, os professores e os livros. Esse processo deve acontecer de maneira prazerosa e lúdica oferecendo oportunidades de novas experiências de leitura para que as crianças possam manifestar seus gostos e sentimentos de forma participativa.

Na Educação Infantil, fase na qual a criança ainda não foi alfabetizada, o professor tem um papel fundamental na construção desse leitor que, por hora, é ouvinte. Chamamos a atenção para a seleção/escolha das histórias que serão lidas/contadas bem como para os instrumentos e estratégias utilizadas nas atividades de leitura, tais práticas devem promover atitudes de interação e construção de sentidos em que as crianças participam ativamente e dialogam com o texto escrito, inferindo, fazendo conexões, expondo suas opiniões e ideias, questionando.

Parece óbvio dizer que as crianças menores, brincam, cantam, pulam, fazem de conta, imaginam, ouvem histórias, no entanto, ainda é possível encontrar pessoas que digam que elas "apenas fazem isso". Ao chegar à creche, percebemos que, em contato com todas essas experiências, as crianças desenvolvem o senso crítico, aspectos motores e sociais, interagem com o meio ambiente, com adultos e com outras crianças e, a medida que vão crescendo, aprendem e ampliam conhecimentos. A prática da narração oral e as atividades de leitura, desenvolvidas nessa fase, figuram como "um componente importante na materialização do conceito de qualidade na Educação infantil.” (BRANDÃO; ROSA, 2011, p. 34)

Assim, mesmo que as ações, mencionadas anteriormente, sejam inerentes ao desenvolvimento e formação das crianças, é importante que o professor/mediador de leitura selecione bons textos, planeje atividades que despertem a atenção e o interesse da criança para os elementos da narrativa, possibilitando a construção de sentidos e desenvolvendo o gosto pelo leitura. Dessa forma,

para que o convívio do leitor com a literatura resulte efetivo, nessa aventura espiritual que é a leitura, muitos são os fatores em jogo. Entre os mais importantes está a necessária adequação dos textos às diversas etapas do desenvolvimento infantil/juvenil. (COELHO, 2000, p.32)

Coelho (2000), sugere que os livros sejam escolhidos de acordo com os estágios de desenvolvimento da criança, propostos pela psicologia ${ }^{3}$, dividindo-os em cinco categorias de

\footnotetext{
3 Piaget (1996), destaca quatro estágios do desenvolvimento infantil: o sensório-motor (até os 2 anos), o préoperatório (2 aos 7 anos), o das operações concretas (7/11 anos) e o das operações formais (11/15 anos ou mais). Para o autor, cada estágio é continuação do anterior.
} 
leitor: 1. O pré-leitor, que subdivide-se em duas fases: a primeira infância (15/17 meses aos 3 anos) e a segunda infância (a partir dos $2 / 3$ anos), na primeira fase, as crianças estão começando a manusear e nomear os objeto e, a presença de um adulto faz-se necessária criando situações que envolvam a afetividade; na segunda fase, as histórias devem ter relação com vivências e acontecimentos próximos ao mundo da criança. 2. O leitor iniciante (a partir dos 6/7 anos), fase na qual a criança é atraída por histórias onde o fraco vence o forte e o bem vence o mal, utilizando-se de astúcia e inteligência. O incentivo e o estímulo são muito importantes nessa fase. 3. O leitor em processo (8/9 anos), nesta fase, as narrativas que apresentam um conflito com resolução no final da história, o humor e o imaginário despertam grande interesse dos leitores. 4. O leitor fluente (a partir dos 10/11 anos), os contos, as crônicas ou novelas são os gêneros que mais interessam nessa fase. 5. O leitor crítico (12/13 anos), leituras que promovam a reflexão e a consciência crítica diante de fatos próprios da adolescência, são os mais indicados nessa fase.

Além da categorização, apresentada por Coelho (2000), formar leitores na Educação Infantil, pressupõe a participação ativa dos pequenos leitores, nas rodas de histórias, onde acontecem a interação entre o professor, seus pares e os livros, mediada pela linguagem. Ao oportunizar o contato diário com os livros e a literatura observa-se que as crianças apresentam um comportamento imitativo do professor, reproduzindo a maneira como a professora conta a história ou segura o livro, promovendo brincadeiras, encenando ou dramatizando as narrativas.

Essas atitudes demonstram a proximidade e a afetividade entre quem conta a história e quem ouve, ademais, "a professora que lê ou conta histórias na Educação Infantil está contribuindo para o desenvolvimento da linguagem e para a socialização de seu grupo, ampliando seu repertório de experiências e sua competência sociocomunicativa.”(BRANDÃO; ROSA, 2011, p. 37)

Nesse sentido, é importante que as atividades de leitura, nessa fase de escolarização, sejam bem planejadas pelo professor/mediador. O trabalho com a Literatura Infantil deve está voltado para a compreensão leitora e para o desenvolvimento de práticas prazerosas, que possibilitem a construção de vínculos entre o pequeno leitor e os textos.

Ao permitir que os alunos participem de forma ativa das aulas de leitura o professor está promovendo o letramento ativo ${ }^{4}$ que

\footnotetext{
${ }^{4}$ Entendemos letramento ativo, a partir dos estudos de (HARVEY e GOUDVIS, FISHER, FREY e LAPP, 2008, HAMPTON e RESNIK, 2009), sobre o ensino de leitura partindo da utilização de estratégias, como a participação
} 
pressupõe a tomada de consciência de estratégias de leitura desde a educação infantil, ou seja, as atividades relacionadas a esse ensino podem iniciar com crianças ainda não alfabetizadas, mas em contato direto com os livros e os diversos suportes de textos para a prática de leitura.” (GIROTTO; SOUZA, 2010, p. 3)

Uma leitura literária bem conduzida além de favorecer o desenvolvimento intelectual das crianças, desperta o prazer pela leitura e, a utilização de estratégias, como instrumento, faz com que essa atividade de leitura torne-se prazerosa e estimulante. Pensando em uma abordagem criativa do texto literário e na escola como promotora do trabalho com leitura, apresentamos nesse artigo uma reflexão sobre a leitura literária na Educação Infantil a partir do texto adaptado para o cordel, Pinóquio (2015), de Sírlia Sousa de Lima e do mesmo conto de fada cordelizado Pinóquio ou preço da mentira (2009), do cordelista Manoel Monteiro, tendo como público alvo crianças com idade entre 3 e 4 anos.

Sugerimos a utilização desse cordel por entendermos que, por se tratar de uma adaptação de um conto de fada, gênero bastante utilizado na sala de aula de Educação Infantil e ainda contar com a presença de personagens maravilhosos, como a fada, uma animal que fala, como o Grilo Falante e um boneco que está constantemente envolvido em aventuras e situações de perigo o texto provocará nas crianças a curiosidade e o encantamento, típicos dessa fase e ainda fará com que as crianças façam conexões com outros textos já lidos/ouvidos e com suas próprias experiências. Vimos também nesse texto, a possibilidade de retomar o repertório de leitura dos alunos e a necessidade de instrumentalizar a utilização do cordel de forma efetiva e eficaz com esse público.

Com isso, objetivamos mostrar que o trabalho com o cordel, na Educação Infantil, recorrendo a aplicação e ensino de estratégias e utilização de métodos, pode oportunizar experiências de leitura lúdicas, que despertem nas crianças o prazer de ler e, que não se limitem apenas aos aspectos formadores, com finalidade pedagógica, prática muito recorrente nas escolas e creches que muito mais afastam do que aproximam as crianças do universo literário, da poesia, da emoção, do sentimento.

\section{Pinóquio e a adaptação para o cordel}

ativa das crianças nos momentos de leitura, oportunidade na qual elas podem ouvir, interagir, e explicitar seus pensamentos. 
Pinóquio, personagem criado pelo italiano Carlo Collodi, ficou conhecido, primeiramente, na Itália quando a pedido dos editores do periódico Gionarle per i Bambini, Collodi escreve e publica pequenos capítulos intitulados Storia di um Burattino, em 1881. Com o enorme sucesso, em 1883 os capítulos tornaram-se livro sob o título, Le avventure di Pinocchio - Storia di um burattino, sendo posteriormente, traduzido e publicado em outras línguas e para outros países. Pinóquio tornou-se um dos personagens mais famosos das histórias infantis.

Pinóquio era um boneco de madeira que gostava de brincar, de estar com outras crianças e não se importava muito com as consequências de alguns de seus atos. Estava sempre envolvido em travessuras que o deixava "em maus lençóis" e, como toda criança, tinha sonhos. O seu era tornar-se uma menino de verdade.

A história se passa em uma pequena aldeia italiana quando o Mestre Cereja, carpinteiro, presenteia o Mestre Gepeto com um pedaço de madeira para que este faça um boneco. Sem saber da característica mágica do pedaço de pau que ganhou, começa a entalhar o boneco dandolhe forma e um nome: "Que nome lhe vou dar? - disse para consigo. - Vou chamá-lo de Pinóquio. Este nome vai dar-lhe sorte. Conheci uma família inteira de Pinóquios: Pinóquio pai, Pinóquia mãe e Pinóquios filhos; e todos iam bem. O mais rico deles pedia esmolas". (COLLODI, 2013, p. 29)

Logo que ganha pernas, Pinóquio foge de casa e, quando apanhado faz com que Gepeto seja preso, essa é só a primeira das travessuras do boneco. Ao voltar sozinho para casa, Pinóquio encontra com o Grilo Falante que lhe aconselha, porém tem a cabeça esmagada por um martelo atirado pelo boneco. E assim ele segue, desviando da escola, encantado com a música que ouve do Teatro de Bonecos onde é preso e, por pouco não é jogado ao fogo como lenha.

Seus desvios sempre o levavam a grandes apuros mas, em seu caminho também encontrava pessoas e seres que tinham compaixão de seu sofrimento e o ajudavam. Em uma dessas ocasiões, após escapar da maldade da raposa e do gato cego, ele encontra uma menina de cabelos azuis que, no decorrer da história constatamos se tratar de uma fada. Ela o salva da morte porém, ao pedir- lhe que ele conte suas desventuras o boneco começa a mentir e seu nariz cresce tanto que ao tentar fugir ele não consegue e mais uma vez a menina dos cabelos azuis o ajuda.

Até tornar-se um menino de verdade, Pinóquio ainda se envolve em muitas aventuras e perigos até parar no interior da barriga de um tubarão onde encontra-se com Gepeto. Muito feliz 
por reencontrá-lo o boneco conta-lhe por onde andou e tudo que aconteceu e decidem fugir e, como o tubarão era velho, sofria de asma e dormia com a boca aberta eles saem devagar, chegam até a língua, conseguem saltar na água e saem nadando.

Ao voltarem a aldeia Pinóquio ainda encontra com a raposa e o gato cego mas não cai mais em suas armadilhas. Já em casa, ele e Gepeto reencontram com o Grilo Falante, que fala sobre o estado de saúde da Fada Azul. Pinóquio consternado com a situação é tomado de bons sentimentos e procura ajudar a fada. Durante o sono, sonha com a fada que o perdoa de todas as travessuras e qual grande é a sua surpresa, ao acordar já não é mais um boneco.

Essa história inspirou muitas adaptações, em diversas mídias e em diversos idiomas. A adaptação mais conhecida vem dos estúdios Walt Disney, de 1940 que ficou conhecida como uma obra prima da animação. Outros filmes e animações também se inspiraram na história do boneco. No Brasil, Monteiro Lobato se inspira no boneco e traz para o Sítio do Pica-Pau Amarelo a personagem Emília, boneca de pano que fala, é muita arteira e vive muitas travessuras e aventuras no sítio.

Como vimos, Pinóquio foi parar nas telas do cinema e da televisão e inspirou a criação de outros personagens com características semelhantes, no entanto, é possível encontrar essa mesma narrativa em um novo formato, na poesia da Literatura de Cordel. Autores e cordelistas viram nessa história a oportunidade de transpor a prosa para a poesia, recriando ou recuperando uma história que vive e sobrevive na imaginação de crianças e adultos. "Qualquer que seja o motivo, a adaptação, do ponto de vista do adaptador, é um ato de apropriação ou recuperação, e isso sempre envolve um processo duplo de interpretação e criação de algo novo". (HUTCHEON, 2013, p. 45)

Na Literatura de Cordel, temos um novo texto, um novo modo de contar a história. Os efeitos sonoros da poesia de cordel e a colocação das palavras acentuam e criam sensações e emoções, como vemos no trecho de Pinóquio ou o preço da mentira (2012), de Manoel Monteiro:

\author{
Cada dia o bonequinho \\ Ganhava um ar de bondade \\ E mais a mais parecia \\ Com um guri de verdade, \\ Para manter um colóquio \\ GEPETO o chamou de PINÓQUIO \\ E deu-lhe a paternidade. \\ (MONTEIRO, 2012, estrofe 06, grifo nosso)
}


$\mathrm{O}$ autor além de primar pelo ritmo, pela rima e pela musicalidade, brinca com as possibilidades de combinação da língua utilizando palavras que fazem parte do universo infantil e tem um tom de afetividade, como "bonequinho" e "guri" e outras que nem sempre contam no vocabulário da criança, como "colóquio" e "paternidade".

No cordel Pinóquio (2015), de Sírlia Sousa de Lima, a autora também prima pelas características estruturais do cordel, escrito em sextilhas, porém a linguagem utilizada por ela é mais simples vai desde a utilização de gírias até uma expressão mais informal, como na sextilha abaixo:

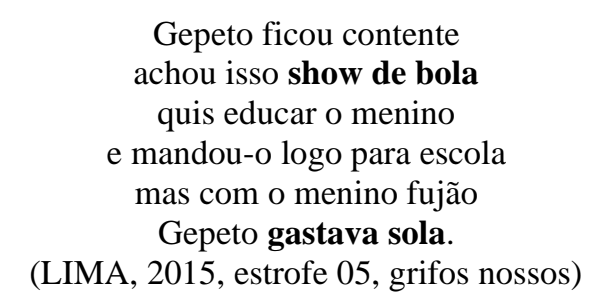

Os recursos linguísticos e estruturais utilizados na poesia de cordel encontram um ótimo espaço na Educação Infantil e apresentam inúmeras possibilidades de aplicação de atividades de leitura literária, ao serem trabalhadas de forma criativa e partindo de estratégias de leitura possibilitam a aproximação do pequeno leitor com a poesia popular do cordel e, nesse caso, por se tratar de uma adaptação de um conto infantil as possibilidades de interação ficam mais fortes e presentes como veremos nas sugestões apresentada.

\section{Leitura Literária na Educação Infantil: métodos criativos}

$\mathrm{Na}$ Educação Infantil, os métodos utilizados na condução das aulas de leitura precisam chamar a atenção do leitor infantil e, o professor como leitor experiente, deve apresentar textos que despertem a curiosidade e criatividade da criança. Por criatividade, "entende-se a operação que confere uma forma a certa interação estabelecida entre o homem e seus mundos externo e interno." (AGUIAR; BORDINI, 1988, p. 62)

Tomando como pressuposto a capacidade da criança de inventar, criar, fantasiar, fazer inferências e conexões, a aplicação de atividades de leitura pautadas na criatividade, levarão a criança a se relacionar com o texto apresentado, buscando dialogar com as imagens ou com a leitura proferida pelo professor e, a leitura de cordel aparece como uma forte aliada na promoção de atividades lúdicas e criativas, sobretudo os que trazem em suas sextilhas a 
presença de animais e dos contos de fadas, tão comumente ouvidos pela crianças na creche e pré-escola.

A forte presença de animais e de aventuras, onde a imaginação se mistura à realidade, nos folhetos, permitem que o pequeno leitor/ouvinte faça inferências e conexões com a sua realidade projetando nos personagens seus medos, anseios e alegrias, dessa forma, podemos dizer que essa projeção é um exercício de intuição e subjetividade onde o sujeito, ao ter contato com os textos, "apreende o mundo, na sua originalidade, conformando-o a suas necessidades." (AGUIAR;BORDNI, 1988, p.64)

Além disso, para Marinho e Pinheiro (2012), “a leitura de cordéis para crianças e/ou com as crianças em sala de aula amplia o repertório infantil de convivência com os bichos e, sobretudo, sua capacidade de brincar com os ritmos da língua e os voos da fantasia.”(p. 61)

Para Aguiar e Bordini (1988), o método criativo está associado à experiências de cunho artístico e, por isso, a escola, não o toma como uma prática de ensino e sim como uma brincadeira descompromissada e sem nenhum objetivo especifico, isso acontece, muitas vezes, pela falta de um planejamento que tenha o aluno, como sujeito ativo e que apresente os seguintes objetivos:

\footnotetext{
1)Estabelecer relações significativas entre componentes do eu e do mundo, em especial da cultura literária. 2) Perceber potencialidades expressivas da literatura e de outros meios de comunicação em relação ao eu e ao mundo. 3) Organizar as relações estabelecidas, valendo-se de códigos culturais, em especial do código linguístico. 4) Materializar tais relações em linguagens diversas, com ênfase na verbal, produzindo textos bem formados. (AGUIAR;BORDINI, 1988, p. 66)
}

Em se tratando de Educação Infantil, os dois últimos objetivos, apresentados pelas autoras, precisam ser adaptados, visto que as crianças nessa fase ainda não possuem o domínio do código linguístico, porém, podem valer-se de outros meios para materializar a compreensão do texto como apresentaremos na proposta a seguir.

O método criativo, pois, traz como proposta o desenvolvimento de atividades de leitura, que levam os leitores a participarem de forma coletiva de todo o processo de construção de conhecimentos. "O método criativo, portanto, apresenta a vantagem de encarar o aluno como individuo e ser social simultaneamente, sem atrofiar sua sensibilidade nem supervalorizar sua capacidade de raciocínio lógico.” (AGUIAR; BORDINI, 1988, p. 71)

\section{Estratégias de leitura: fazendo conexões}


É na escola que muitas crianças tem seus primeiros contatos com a leitura e com os livros, chamamos a atenção para a importância do professor/mediador como promotor de momentos e atividades de leitura literária significativas que conduzam as crianças ao mundo dos sonhos e fantasias de forma lúdica e prazerosa. Nessa perspectiva, devemos considerar que as atividades de leitura precisam ser bem planejadas para que as crianças, que tem seus primeiros contatos com o texto literário na creche, sintam-se motivadas a ler, ler além da decodificação, fazendo relações e conexões para a compreensão do texto lido.

Nenhuma tarefa de leitura deveria ser iniciada sem que as meninas e meninos se
encontrem motivados para ela, sem que esteja claro que lhe encontram sentido.[...] As
situações de leitura mais motivadoras são as mais reais: isto é, aquelas em que a
criança lê para se libertar, para sentir o prazer de ler, quando se aproxima do cantinho
de biblioteca ou recorre a ela. [...] ... a motivação está intimamente relacionada às
relações afetivas que os alunos possam ir estabelecendo com a língua escrita. (SOLÉ,
1998, p. 91-92)

O que a autora sugere é que as situações de leitura sejam bem elaboradas, ou seja, o professor/mediador deve estar atento à escolha dos textos, para que os alunos desenvolvam o gosto pela leitura. Textos que permitam que o leitor avance em seu próprio ritmo e utilize suas estratégias de leitura.

Segundo Solé (1998, p.72), as estratégias de leitura são "como um tipo particular de procedimentos" que facilitam a leitura e devem ser ensinados com o intuito de formar leitores autônomos. Ao ler, várias ações são ativadas na nossa mente, dentre elas as inferências, as conexões, a sumarização, a síntese, que denominamos de estratégias de leitura e pelas quais extraímos informações sobre o texto lido ou sobre as histórias lidas/contadas por um adulto.

A estratégia da conexão, apresenta-se como uma possibilidade eficiente para a compreensão do texto literário levando a criança a interagir com o texto através de experiências anteriores de leitura ou da sua própria vivência. Acerca das conexões, Girotto e Souza (2010), afirmam que:

[...]fazer conexões com experiências pessoais facilita o entendimento. As vivências e conhecimentos prévios dos leitores abastecem as conexões que fazem. [...] Ensinar as crianças a ativar seus conhecimentos prévios, bem como seus conhecimentos textuais, e pensar sobre suas conexões é fundamental para a compreensão. (p. 67)

As autoras também apresentam três formas de conexão:

- Texto-Texto: conexão que o leitor estabelece entre o texto atual com outra leitura já realizada por ele, seja do mesmo gênero ou não;

- Texto-Leitor: conexões entre o texto e as vivências do leitor; 
- Texto-Mundo: conexão estabelecida entre o texto lido e conhecimentos de ordem mais global.

Na Educação Infantil, os momentos de leitura são sempre repletos de expectativa, atenção e encantamento. A cada momento da narrativa as crianças vão buscando pistas e fazendo conexões para compreender o desenrolar da história e perceber nos personagens algo de semelhante com eles ou com suas vivências. Esse processo de interação entre o texto, o leitor e o mundo só será possível se o professor dispuser de bons textos, que permitam às crianças a compreensão das ideias centrais do texto buscando ao máximo os seus conhecimentos prévios, seja por meio de leituras realizadas em outros momentos, seja por intermédio de suas vivências ou de fatos de ordem coletiva.

Justamente porque quando lemos para crianças a primeira coisa que elas fazem é procurar no texto conexões com suas vivências. [...] Assim, mesmo os menores se identificam ou procuram pontos semelhantes entre asa histórias e suas experiências de vida. Tudo isso ajuda essas crianças e nós educadores a alargarmos o conhecimento de mundo, os sentimentos com relação aos outros e as coisas, e facilita a compreensão que teremos de novos textos, de novas histórias. (GIROTTO; SOUZA, 2010, p. 36)

Nesse sentido, é importante ressaltar a importância de ensinar estratégias de leitura desde os primeiros contatos da criança com a literatura, levando em conta o interesse do professor em formar leitores proficientes. A conexão, como estratégia de leitura, permitirá que o pequeno leitor ative seus conhecimentos prévios, aproximando cada vez mais a criança dos textos e das leituras, além de ser uma atividade significativa e prazerosa.

\section{Pinóquio na sala de aula: propostas de leitura literária na Educação Infantil}

Para a primeira sugestão metodológica, utilizamos o conto de fada, cordelizado, Pinóquio, de Sírlia Souza de Lima, que conta a história de Gepeto, um artesão solitário, que ansiava por uma companhia e, ao ganhar um pedaço de madeira de seu amigo marceneiro, Mestre Cereja, começa a entalhar um boneco ao qual ele dá o nome de Pinóquio que logo depois ganha vida e vive muitas aventuras.

Por se tratar, inicialmente de um boneco, brinquedo que faz parte do universo das crianças menores, com o objetivo de adentrar na história, a professora pode levar para a sala um boneco de madeira, trapezista, popularmente conhecido por "Mané Gostoso 5". Enquanto

\footnotetext{
${ }^{5}$ Boneco feito de madeira e fios ou cordões que colocados em forma de $\mathrm{X}$ fazem com que o boneco, ao pressionar a madeira que os sustenta, faça acrobacias. O brinquedo também foi criado por um artesão.
} 
manuseia o boneco, fazendo acrobacias, a professora pode, de maneira informal, fazer perguntas sobre ele: Quem sabe qual o nome dele? De que ele é feito? O que ele está fazendo? Onde será que ele mora? Vocês já viram um boneco igual a esse?, a fim de buscar os conhecimentos prévios das crianças.

Figuras 1 e 2 - Boneco trapezista "Mané Gostoso"
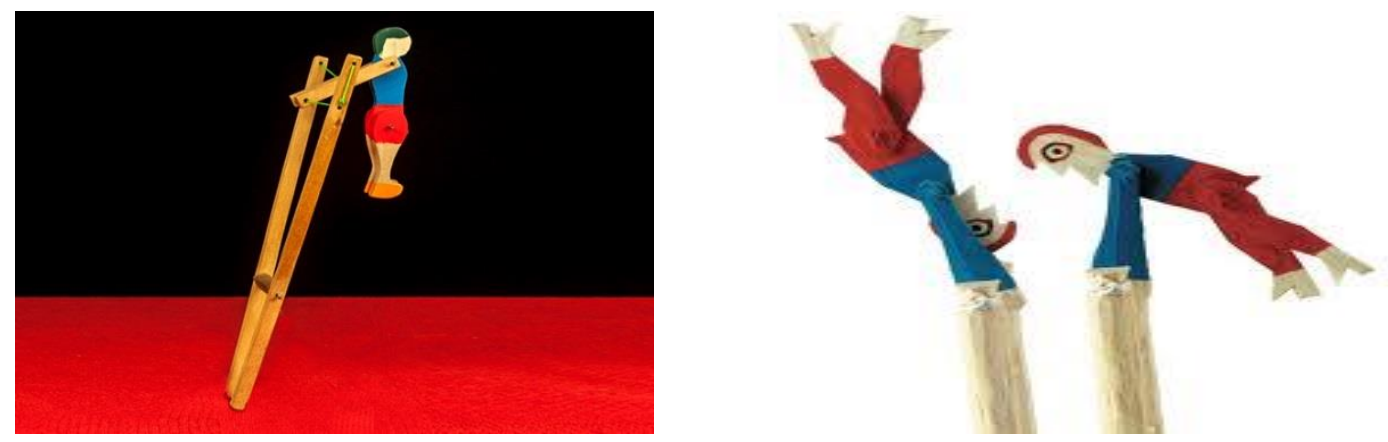

Fonte: Artesanato Sustentável/Na sombra do Juazeiro ${ }^{6}$

Esse momento deve acontecer em uma roda de conversa onde as crianças sintam-se a vontade para interagir com a professora e colegas. É importante que as crianças tenham espaço para falar, serem ouvidas e construir sentido àquilo que leem/ouvem afinal,

a finalidade desse diálogo não é avaliar o nível da compreensão das crianças nem fazer com que elas respondam em coro às perguntas formuladas. A ideia é contribuir para o seu engajamento numa atividade de construção de sentido que pode ser compartilhado, confrontando ou ampliando com base em outros sentidos igualmente construídos e expressos na conversa sobre o texto lido na roda. (BRANDÃO; ROSA, 2011, p. 43)

Após essa conversa inicial o professor pode apresentar o livro com a história que será lida, mostrando que o personagem principal tem algumas características do boneco apresentado anteriormente. Por se tratar de uma adaptação para cordel, a leitura será feita de forma cadenciada, articulando claramente as palavras para que as crianças compreendam a narrativa, localizem os personagens e suas ações. A leitura desse tipo de texto tem características

\footnotetext{
6 Disponível em: http://artesanatosustentavel.com.br/product/mane-gostoso/ http://nasombradojuazeiro.com.br/2018/10/11/mane-gostoso-sua-historia-e-do-seu-criador/. Acesso em: 22/02/2019.
} 
especificas e requer que o professor imprima ritmo e musicalidade ao texto. Como estamos lidando com crianças de 3-4 anos, é possível que haja a necessidade de uma segunda leitura, inclusive a pedido das próprias crianças.

A compreensão oral do texto ocorrerá logo após a leitura, nesse momento a professora apresentará figuras representativas dos personagens, previamente providenciadas, mostrando às crianças para que elas construam coletivamente um gráfico organizador e possam perceber e compreender os aspectos da história e dos personagens. Como as crianças, na fase trabalhada, ainda não se apropriaram do código escrito a professora lê o nome dos personagens para que as crianças colem a figura no lugar correto. Após a colagem, a professora vai retomando, oralmente, as ações e características de cada um por meio de perguntas.

\begin{tabular}{|c|c|c|c|}
\hline PINÓQUIO & GEPETO & GRILO FALANTE & FADA MADRINHA \\
\hline $\begin{array}{l}\text { Quem era Pinóquio? } \\
\text { O que ele fez? } \\
\text { Por onde ele andou? } \\
\text { O que aconteceu com } \\
\text { ele? Por que? }\end{array}$ & $\begin{array}{l}\text { Quem era Gepeto? } \\
\text { O que ele fazia? } \\
\text { Onde ele foi parar? } \\
\text { Por que? }\end{array}$ & $\begin{array}{l}\text { Quem era o Grilo } \\
\text { Falante? } \\
\text { De onde ele veio? } \\
\text { Você já viu um } \\
\text { grilo? }\end{array}$ & $\begin{array}{l}\text { O que a Fada } \\
\text { Madrinha fez? } \\
\text { Ela era boazinha? } \\
\text { O que ela disse a } \\
\text { Pinóquio? } \\
\text { Você já ouviu falar } \\
\text { em fada? }\end{array}$ \\
\hline
\end{tabular}

O quadro proposto além de retomar a história lida ainda fará com que as crianças façam conexões com suas vivências e com outras leituras, feitas em momentos anteriores, tendo em vista que ao colar os personagens eles serão capazes de identificá-los fazendo relação entre a imagem e a palavra, lida pela professora e, ao serem questionados, poderão expor suas ideias e conhecimentos a cerca da história. Uma outra possibilidade de leitura seria a retomada das sextilhas que referem-se aos personagens, por exemplo, a professora lê uma sextilha do cordel e as crianças pegam a figura do correta para tecer os seus comentários.

$$
\begin{aligned}
& \text { Quando eis que de repente } \\
& \text { aparece uma fadinha } \\
& \text { deu-lhe um sopro de vida } \\
& \text { era uma Fada Madrinha }
\end{aligned}
$$




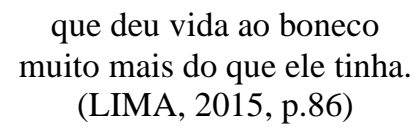

As atividades apresentadas permitem que a criança participe ativamente da leitura fazendo interrupções, apresentando suas opiniões e dando sugestões. Durante a aplicação das atividades de leitura é possível retomar conhecimentos prévios, o que facilita a compreensão do texto além de aproximar o pequeno leitor de várias experiências de leitura quando nos propomos a apresentar um conto de fada tradicional em um novo suporte e uma nova linguagem, o cordel.

\section{Uma abordagem criativa}

Como segunda proposta de intervenção selecionamos o conto de fada cordelizado, Pinóquio, de Manoel Monteiro, ilustrado por Jô Oliveira, no suporte livro. O formato do livro, as ilustrações e a divisão das estrofes nas páginas, do livro, oferecem possibilidades de um planejamento de atividades de leitura literária e, por se tratar de crianças que estão na segunda infância as imagens e os textos curtos, dramatizados ou lidos pelo professor, tendem a manter a atenção e o interesse da criança, no momento da leitura, como é possível perceber no excerto.

\begin{tabular}{|c|}
$\begin{array}{c}\text { Gepeto, artesão famoso, } \\
\text { Em sua marcenaria } \\
\text { Dava vida a simples tábuas, } \\
\text { Serrava, colava, unia } \\
\text { Com tanto amor, tanto afeto, } \\
\text { Que ao fim o objeto } \\
\text { Um filho lhe parecia. } \\
(. . .)\end{array}$ \\
$\begin{array}{c}\text { Foi a casinha singela } \\
\text { Do compadre Cerejeira } \\
\text { Outro artesão, seu amigo, } \\
\text { E duma tábua "maneira" } \\
\text { Que lá pôde conseguir } \\
\text { Começou a construir } \\
\text { Um boneco de madeira. }\end{array}$ \\
Mmonteiro
\end{tabular}

A aplicação de uma prática criativa, na sala de aula, requer o planejamento das seguintes etapas, apresentadas por Aguiar e Bordini(1988, p. 71), 1) constatação de uma carência; 2) 
coleta desordenada de dados; 3) elaboração interna dos dados; 4) constituição do projeto criador; 5) elaboração do material e 6) divulgação do trabalho.

Como dissemos anteriormente, essas etapas sofrerão algumas alterações para adaptarse às necessidades da Educação Infantil, assim, a seguir, elaboramos uma proposta de unidade de ensino de leitura para crianças de 3/4 anos, com foco no currículo por atividades.

\section{Unidade de Ensino}

\section{Currículo por Atividades}

Conteúdo: Brincando com a linguagem

\section{Material:}

MONTEIRO, Manoel. Pinóquio: histórias do mundo em cordéis. São Paulo: DCL, 2009.

\section{Objetivo:}

Proporcionar às crianças a possibilidade de realizar diferentes leituras em diferentes linguagens, contribuindo para a formação e ampliação do repertório de leitura na Educação Infantil.

\section{Procedimentos didáticos}

\section{Constatação de uma carência:}

O professor, percebendo a carência do trabalho com literatura de cordel, nas salas de aula de Educação Infantil, em contrapartida da vasta utilização dos contos de fadas, levará para a sala um conto de fada, conhecido das crianças, adaptado para o cordel.

Para deixar as crianças mais a vontade com o texto, a professora, em uma roda de história, explorará, de forma oral, os conhecimentos prévios das crianças acerca da história, personagens, narrativa, conflitos. O professor pode sugerir que uma das crianças, conte, de forma espontânea a história.

\section{Coleta desordenada de dados:}

A primeira leitura, será feita, em forma de perguntas, a partir da apreciação da ilustração da capa. O professor pode levar para a sala de aula alguns dos elementos que aparecem na ilustração para conduzir as perguntas, a sombrinha que aparece na mão do boneco, um boneco de madeira articulado.

A pós essa primeira leitura o professor, então, lê as três primeiras sextilhas do texto cordelizado, que nessa experiência utilizará o suporte livro e, após a leitura apresenta a ilustração correspondente. O professor pode enriquecer esse momento fazendo perguntas sobre a ilustração e o texto, por exemplo:

- O que vocês estão vendo na ilustração? 
- O que está acontecendo?

- Qual o nome desse personagem?

Por se tratar de uma turma ainda não alfabetizada, a leitura das sextilhas poderá tomar mais de uma aula. Isso pode aguçar a curiosidade das crianças para saber como continua a história. Será que ela termina do mesmo jeito do conto de fada?

\section{Elaboração interna dos dados:}

Essa etapa será realizada durante a semana quando da retomada da leitura do texto e apreciação das ilustrações. A medida que a leitura avança o professor pode sugerir a produção de um boneco para contar a história para as outras turmas.

\section{Constituição do projeto criador:}

Essa etapa será de ensaio onde as crianças escolherão as sextilhas que querem recitar. Por se tratar de um texto grande para essa faixa etária a professora também auxiliará na leitura.

\section{Elaboração do material:}

Utilizando material, previamente separado, a professora orientará as crianças para a construção do boneco que será utilizado na "contação de história" realizada nas outras turmas. Após a construção do boneco a professora, em conversa informal, seleciona as crianças que vão contar a história, em cordel.

\section{Divulgação do trabalho:}

A turma fará uma divulgação prévia do que acontecerá no ambiente externo às salas de aula e, no dia marcado para a socialização da história se encontrarão no pátio da escola para a conclusão do trabalho elaborado.

\section{Considerações Finais}

É na Educação Infantil, que os primeiros contatos das crianças, com a leitura de literatura acontece. É o momento da descoberta, das interações com os adultos e com seus pares, momento em que imaginação e fantasia se misturam à realidade, quando a criança encontra nas histórias lidas, pela professora, algo que lhes parece familiar. O papel do professor/mediador nessa fase é preponderante para o desenvolvimento de leitores proficientes.

Reforçamos a necessidade de incluir a leitura literária no planejamento diário da professora. Vale frisar que, o planejamento deve levar em consideração a experiência leitora dos alunos, a capacidade de interagir com os textos e uma metodologia que possibilite o 
afloramento do prazer de ler e isso só é possível quando o professor seleciona bem o seu material de leitura.

Os contos de fadas são fontes inesgotáveis de saberes e fazem parte do nosso repertório de histórias desde a mais tenra infância e o cordel, por sua característica popular e lúdica, vem adaptando essas histórias nos oferecendo a possibilidade de acentuar o trabalho com esse tipo de texto na Educação Infantil. Um trabalho bem feito e bem elaborado, com a leitura literária, pode render muitos frutos e levar os pequenos leitores a criar suas próprias histórias e participar ativamente do processo de ler.

O trabalho que apresentamos traz propostas de atividades de leitura para Educação Infantil e, em detrimento desse público, sugerimos apenas atividades orais, pois as crianças nessa fase ainda não encontram-se alfabetizadas, porém apresentam plenas condições de fazer outras leituras que possibilitam seu encontro com os textos escritos. Aqui, nos referimos às experiências e vivências dos alunos, os conhecimentos prévios, que tornam possível essa aproximação.

Apresentar a leitura de literatura aos pequenos leitores é oportunizar o contato com experiências que vão além dos livros, é fornecer meios para que as crianças descubram o encantamento das histórias e percebam que através delas é possível conhecer um pouco mais sobre si e sobre o mundo que as cerca. A presença do professor/mediador nesses momentos é fundamental, na Educação Infantil, é ele quem fará com que a história lida/contada seja significativa, selecionando bons textos e estratégias que contribuam para a formação de leitores.

Estratégias de leitura bem planejadas levam as crianças a interagir com a obra e, a conexão, enquanto estratégia de leitura, possibilita a interação do leitor/ouvinte com o próprio texto, quando este reconhece elementos que o fazem levantar hipóteses sobre do que se trata a história ou encontra pontos de intersecção com outras histórias conhecidas, quando compara as situações apresentadas no texto com suas vivências e também com situações já experimentadas na comunidade, de forma coletiva.

Dessa forma, é possível perceber que a conexão é uma estratégia que promove o diálogo e amplia os conhecimentos do leitor. Por essa razão, optamos por utilizá-la como sugestão de atividade de leitura na Educação Infantil tendo em vista que, para a criança que ainda não ler, a aplicação de ações que motivem e retomem os conhecimentos prévios dos alunos os aproximará cada vez mais das leituras literárias aumentando o interesse pela leitura além de torná-los sujeitos ativos do ato de ler. É importante salientar que a ludicidade e a criatividade 
devem ser pontos principais no planejamento das atividades de leitura para crianças, da Educação Infantil, são eles que promoverão experiências de leitura prazerosa e rica em significados.

\section{Referências}

AGUIAR, Vera Teixeira de; BORDINI, Maria da Glória. Literatura, a formação do leitor: alternativas metodológicas. Porto Alegre: Mercado Aberto, 1988.

BRANDÃO, Ana Carolina Perrusi; ROSA, Ester Calland de Sousa. Ler e escrever na Educação infantil: discutindo praticas pedagógicas. Belo Horizonte: Autêntica Editora, 2011.

COELHO, Nelly Novaes. Literatura infantil: teoria, análise, didática. São Paulo: Moderna, 2000.

COLLODI, Carlo. As aventuras de Pinóquio: história de uma marionete. Tradução e notas Leda Beck. São Paulo: Martin Claret, 2013.

GIROTTO, C.G.G.S; SOUZA, Renata Junqueira. Estratégias de leitura: para ensinar alunos a compreender o que leem, IN: SOUZA, Renata Junqueira [et al.]. Ler e compreender: estratégias de leitura. Campinas-SP: Mercado das Letras, 2010.

LIMA, Sírlia Sousa de. Pinóquio. IN: Contos encantados em cordel. Natal-RN: CJA Edições, 2015.

MARINHO, Ana Cristina; PINHEIRO, Hélder. O cordel no cotidiano escolar. São Paulo: Cortez, 2012.

MONTEIRO, Manoel. Pinóquio: histórias do mundo em cordéis. São Paulo: DCL, 2009.

SOLÉ, Isabel. O prazer de ler. Revista Leitura e Vida, n.3, Newark/EUA. Associação Internacional de Leitura, 1995.

SOLÉ, Isabel. Estratégias de leitura. Porto Alegre: Artmed, 1998.

VELOSO, Geisa Magela. Leitura como produção de sentidos. IN: Fundamentos e Metodologia da Língua Portuguesa I. Universidade Estadual de Montes Claros - UNIMONTES. Montes Claros-MG, 2015.

VIEIRA, Eziel. Carlo Collodi: o criador do Pinóquio. Biografias e Curiosidades. Disponível em: http://biografiaecuriosidade.blogspot.com.br. Acesso em: 11/08/2019. 